\title{
SELECTED PROBLEMS ON POLISH-RUSSIAN CROSS-BORDER COOPERATION BASED ON THE EXAMPLE OF THE VISTULA LAGOON
}

\author{
TADEUSZ PALMOWSKI \\ Institute of Geography, University of Gdańsk \\ Bażyńskiego 4, 80-952 Gdańsk, Poland \\ e-mail: geotp@univ.gda.pl
}

\begin{abstract}
This paper presents selected problems on Polish-Russian cross-border cooperation based on the example of Vistula Lagoon (historical, political and economical background, environmental factors, relationships after May 1st 2004, when the boundary has been the external European Union border).

Key words: Vistula Lagoon, cross-border cooperation, border and Baltic shipments
\end{abstract}

\section{INTRODUCTION}

The Vistula Lagoon is a wide spread water basin on the Polish Russian borderline separated from the Baltic waters by the narrow Vistula Spit. The only link with the sea runs through the Strait of Baltiysk, which lies beyond the country's border, seriously hindering operations. The Polish side covers approximately $328 \mathrm{~km}^{2}$, i.e. a basin $40 \mathrm{~km}$ long and 7 to $9 \mathrm{~km}$ wide. Several rivers flow into the Lagoon, enjoying shipping traffic of fishing, trade and sport vessels: Nogat, Wisła Królewiecka, Szkarpawa, Elblag. The Vistula Lagoon, one of the greatest coastal water basins in the southern Baltic has considerable economic significance, primarily as an important link in the inland and marine water communication system, as an area of successful fishing and a fresh water basin. The adjacent land features certain natural mineral and power resources, and well developed agricultural and industry sectors as well as environmental tourism and recreational attractions. 
The Vistula Lagoon is a natural link joining the east and central European river network. Two ports lie along its coasts: Kaliningrad and Elblag linked by a $2-5 \mathrm{~m}$ deep fairway. The picaresque sheltered waters of the Vistula Lagoon are an excellent area for water sports and sailing. It is also a place for winter sports with the long lasting ice cover of the basin.

Around the Vistula Lagoon and the mouth of the Elblag River there are in total twelve small ports and havens. The main ports include Nowa Pasłęka, Frombork, Tolkmicko, Piaski, Krynica Morska and Kąty Rybackie. A $68 \mathrm{~km}$ long and 2-5 km wide fairway links these ports through Baltiysk and the mouth of Szkarpawa River along the middle of the Lagoon. Efforts of the Maritime Office in Gdynia led to dredging a $2.7 \mathrm{~m}$ deep fairway to Elblagg and fairway branching toward Krynica Morska, Tolkmicko and Frombork.

The best known Polish port of the region is Elblag. There were periods in the town's centuries long history when the port played an important role in the development and growing prosperity of Elblag. In the period between World War I and II the Elblag port, lying within the borders of Eastern Prussia, served almost solely inland shipping vessels due to minor depth and bathymetric problems. After World War II, Elblag was classified to the group of small ports. At the beginning of the nineties the town undertook measures to revitalize the Elblag port. At present Elblagg is the biggest Polish port on the Vistula Lagoon, lying on the Elblagg River $6 \mathrm{~km}$ from its outlet to the Lagoon.

The end of Elblag's links with the sea, and the same the relapse of the Elblag port to a peripheral port, resulted from the situation created by the USSR in 1945 when the state border of Polish People's Republic and USSR ran across the Vistula Lagoon, from Elblag and other Lagoon ports through the Strait of Baltiysk to the Baltic Sea (contrary to the agreement between Poland and USSR of 16 August 1945). The water border in normal international relations is not an obstacle to international sea shipping. The freedom of passage for seagoing vessels means sailing from the area of one country in order to reach another country.

Closing access to shipping in the Strait of Baltiysk resulted in attempts to develop other, independent passages to the Baltic Sea. Plans have been developed to dig across the Vistula Spit and to modernise the inland waterway route from Elblag to Gdańsk. A shipping connection along this route established in 1947 did not show development dynamics. Cargo shipped was dominated by ship fittings produced in Elblag for the shipyard industry. Passenger traffic focused on the Gdańsk-ElblagKrynica Morska.

\section{POLISH-RUSSIAN RELATIONS}

With May 12004 the border between Poland and Russia on the Vistula Spit and Vistula Lagoon is the border between EU and Russia. According to many, including 
former President Putin, the Kaliningrad Oblast' may be a pilot or laboratory of mutual EU and Russia relations. Cross-border cooperation development in Europe is based on the European Framework Convention on cross-border cooperation of territorial communities and authorities (Madrid Convention) of 1980 and the European Charter of Border and Cross-border Regions adopted in 1981.

The Treaty on Neighbourly Relations and Cooperation between the Republic of Poland and the Russian Federation dates back to 1992. A relatively new form of Russian policy of the Oblast authorities involves agreements with Polish partnersVoivodships: Pomorskie, and Warmińsko-Mazurskie concluded in 2001. At the local level, a number of town self governments signed agreements, e.g. Elblagg and Kaliningrad, Elblag and Baltiysk.

The basis of international cooperation in establishing protected cross-border regions in this part of Europe could be based on the so called Wigry Declaration signed in 1992 in Wigry by governmental representatives, territorial authorities and scientists from Poland, Russia, Lithuania, Latvia, Belarus and Ukraine. The Declaration assumes close cooperation of the signatories in protection of the environment and in eco-development.

In recent years favourable conditions were created for the development of a modern sea port in Elblag operated as a municipal port, managed by the town.

Further development of the sea port is conditioned by the openness of shipping routes, improved technical condition of facilities, wharfs as well as port and tourism infrastructure, and port promotion. It is assumed that the port in Elblag will ultimately be open to ships of $3 \mathrm{~m}$ draught and up to $100 \mathrm{~m}$ long, i.e. of 2.5 thousand GT. Depending on the economic development of the region and port capacity as well as shipping conditions on the Vistula Lagoon and the fairways, the Elblag port will handle shipments in the following directions:

- border shipments-bulk and general cargo in border cooperation mainly between Elblag and Kaliningrad,

- Baltic shipments-cargo shipments between Elblag and small Baltic ports,

- local transport—cargo shipment between Elblag and Gdańsk agglomeration ports, supplies to ports of the Vistula Lagoon,

- east-west shipping —along inland waterways joining Elblagg with Kaliningrad and Klaipeda with Berlin. (Luks 2006 a).

The direct outskirts of Elblagg will be the Baltic ports, mainly Kaliningrad Oblast' (Baltiysk, Kaliningrad, Svetly), as well as small ports in Scandinavia and Germany, and from time to time North Sea ports. Elblag will also be a feeder port for Gdańsk and Gdynia using an inland waterway (Szkarpawa). With time German river ports may become foreign inland outskirts of the port connected with the Lagoon by a system of Polish and German inland waterways. The major cargo stream projected in international turnover of Elblag port will embrace goods traded with Kaliningrad. Trade with the Kaliningrad Oblast' may embrace a wide range of both exported and imported goods. 
To ensure a stable and independent waterway linking the Lagoon with the Baltic Sea, a concept keeps reappearing for a canal across the Vistula Spit, which would stimulate the link of Elblag with the ports of Gdańsk and Gdynia and connections with small Baltic ports. Opening of the Lagoon may also have an impact on stimulating sailing tourism, which will result in greater traffic in tourist locations around the Lagoon.

The functioning of Elblag port has depended on political factors since 1945 . The present situation results from a one sided decision of the USSR, separating surprisingly and without precedence not only the Lagoon water basin but the Vistula Spit itself. This was associated with the military nature of the Kaliningrad Oblast' since the end of World War II. Though mutual agreements in force ensured free passage of Polish ships through the Strait of Baltiysk, these remained solely declarations on paper. Before 1989 Polish authorities did not assert Polish rights and did not fully readdress the problem in the following years. Polish diplomacy was not prepared to handle the hard and fundamental talks with their eastern partner (D.R. Bugajski 2006). Shipping by foreign flagged ships, yachts as well as Polish vessels, and sailing between Polish and Russian ports around the Vistula Lagoon were prohibited.

Geopolitical changes of the nineties of XX century opened the subject of freedom of shipment on the Lagoon in Polish and Russian talks. In December 1990, the yacht "Misia II" under the skipper Edmund Krasowski, a Member of Parliament at the time, as the first sailed across the Strait of Baltiysk. The episode was widely covered by the Polish mass media. However, similar attempts ended with detentions by the Russian border guards.

One of the first diplomatic negotiation rounds on the issue took place in July 1991 in Warsaw. Talks resulted in confirming legal access to Lagoon waters for merchant vessels flying the flag of both countries. Nevertheless, ships of other countries were barred access under the argument that fairways were on USSR territorial waters, therefore, ship passage fell under domestic regulations and not international law. In the following years the Polish side, in relations with Russia, aimed at signing relevant provisions to make shipping on the water basin possible not only for trading vessels but all vessel types (e.g. yachts and other recreational and sports units) Polish flagged and flying other flags. The abstemious standing towards Polish pro-posals Russia explained by, inter alia, environmental reasons and difficulties in the eventual maintenance of the fairway in good condition. Russia also referred to the problem of bathymetry, including the small depth of the basin and the problem of dredging exceeding its financial capacity and, in economic terms, remaining rather non cost effective. Nevertheless, earlier agreements were not fully respected. Although agreements had been reached in July 1991 the Strait of Baltiysk remained closed even for Polish flagged ships. Attempts were made to break the deadlock in 1992 in the process of developing the Polish Russian international treaty but neither party changed their standing on the issue. During talks held by the States' Presidents in 1993, with the presence of Jurij Matoczkin, the governor 
of the Kaliningrad Oblast' of the Russian Federation at the time, the final deadline for regulating the issue was projected as early as by the end of 1993 . The Presidents of the two countries declared that: "Recognising the significance of cooperation in the Strait of Baltiyskand the Vistula Lagoon for regional development, not only in terms of shipping, the Presidents will undertake measures for competent departments to prepare an agreement regarding the above by the end of 1993, taking into account economic, ecological technical and navigational conditions and the position of the Polish party"1. The deadline passed but the problem remained unsolved. Further attempts to regulate the issue were undertaken many times by the Polish Russian Council for Regional Cooperation of the Republic of Poland with the Russian Federation, inter alia, the Joint Commission for Environmental Protection and Comprehensive Spatial Development of the Vistula Lagoon. The signing of an agreement regarding shipping on the Vistula Lagoon was also a task of the Ministry of Transport and Maritime Economy included in the Polish strategy for foreign policy towards Russia in 2001. Similarly, measures aimed at providing access and freedom of shipping in the water basin to vessels of third countries, were undertaken by the Ministry of Foreign Affairs and the Ministry of Infrastructure. In December 2004, the Polish Ministry of Foreign Affairs sent a note to the Russian party including a draft agreement on Vistula Lagoon shipping with a proposal to revive talks on signing an agreement. In 2005, the project was analysed by the Ministry of Transport of the Russian Federation. In autumn 2006 the Russian side presented Poland with a new draft agreement. Mutual talks were to be held in November but did not take place.

Starting May 2006 Russians blocked shipping on their side of the Vistula Lagoon without any warning. The official reason was Poland's accession to the EU and related, according to the Russian side, expiry of the international agreement regulating shipping on the Lagoon and a need to conclude a new agreement. Shipping on the Lagoon between ports of the two sides practically died down. The problem of access to the Polish part of the Lagoon became acute with a detrimental effect on all Polish gminas round the Lagoon and the Kaliningrad Oblast'.

During the VIII meeting of the Polish Russian Permanent Transport Committee, held in November 2006 in Svetlogorsk, Ministers expressed their will to regulate the problem of shipping on the Vistula Lagoon as quickly as possible and open a ferry connection between the ports of Gdańsk, Elbląg and Baltiysk.

Though talks had been in progress from the beginning of the nineties, thanks to a more lenient attitude to restrictions for shipping in the Strait of Baltiysk, the Russians opened the Lagoon to ships flying all flags along the entire fairway leading to Kaliningrad, freedom of shipping was restored. A shipping line was instated between Polish and Russian ports in the Lagoon. Such a liberation of shipping rules resulted in stimulation of ports on both sides. The only remaining restriction in force involved

1 Wspólna Deklaracja Polsko-Rosyjska [Joint Polish-Russian Declaration], Warsaw 25 August 1993, Zbiór Dokumentów 1993, no 3 
a ban for other than Polish and Russian flagged ships to cross the Russian part of the Lagoon.

On September 1 2009, the Prime Ministers of Poland and Russia signed, in Sopot, a long awaited agreement, between the government of the Republic of Poland and the Government of Russia, regarding shipping on the Vistula Lagoon. The agreement was to come into force on the day of signing, then upon ratification, which the Council of Ministers of the Republic of Poland approved on 19 October 2009. Ship traffic to Polish ports on the Vistula Lagoon is also regulated by the Order of the Russian Federation Government dated 15 July 2009 on providing access for foreign flagged ships sailing to or from ports.

The agreement on freedom of shipping on the Vistula Lagoon signed for a period of five years gives rise to questions as to its implementation in practice. The key disputable issues involve acceptance by the Polish party of a mutual clause in the agreement allowing for traffic suspension due to defence, safety related reasons and protection of the natural environment. Restrictions for granting a permit for sailing of vessels flying the flag of third states are of proscriptive nature, vessels that wish to cross the Strait of Baltiysk must inform the marine port administration in Kali ningrad 15 workdays before the planned date of entry. In practice, this hinders and in some cases makes a passage to Elblag impossible (Frankowski 2010).

The actual enforcement of the agreement, starting spring 2010, will have a major impact on stimulating the sea port in Elblag and the tourist sector of small ports around the Vistula Lagoon. Revival of trading on the Kaliningrad-Elblag route is connected with import of about 10 thousand tons of coal monthly. Import of aggregate is also projected. Agreements concluded by Elblag port with Russian companies in Kaliningrad Oblast' project the transport of 200-300 thousand tons of cargo annually through Elblagg to Poland starting spring 2010. (Frankowski 2010).

Freedom of shipping in the Russian part of the Lagoon for ships and yachts flying all flags and construction of the canal across the Vistula Spit, contrary to the quite common opinion in Poland, are not competitive objectives. Quite conversely, the construction of the canal would enhance the attractiveness of the entire water basin, including its Russian part.

The present state of the waterway Elblag-the Strait of Baltiysk does not allow for ships of more than 1 thousand DWT. A fairway 5 meters deep is required for ships of 3-4 thousand DWT. The technical state of the fairway today does not ensure a standing connection. In economic terms this can only be assured by a canal across the Vistula Spit. Access to the Baltic across Russian waters means the modernising of at least a $30 \mathrm{Mm}$ sector of the fairway. In the case of the canal this may be only $5 \mathrm{Mm}$. Over half of the fairway length to the Strait of Baltiysk runs through Russian waters and the Federation is not interested in upgrading and maintaining necessary parameters in their part of the fairway. The entire burden would have to be incurred by the Polish side. This would mean dredging by 1-2 m the Russian fairway along a $15 \mathrm{Mm}$ section and maintenance of its parameters. 
Apart from political aspects this would be a permanently loss-making undertaking (Luks 2006 b).

The fairway from the Vistula Lagoon through Szkarpawa and Martwa Wisła is not an alternative for the future canal. This $30 \mathrm{Mm}$ and $2.5 \mathrm{~m}$ deep route requires modernisation and conversion of two lock gates: Gdańska Głowa and Przegalin. The 8.5 clearance of the new suspension bridge on Martwa Wisła in Gdańsk means that taller vessels would have to detour through Górki to the Gdańsk Bay to reach TriCity ports. The construction of a canal across the Vistula Spit would mean that the distance to Gdańsk from entry to the sea would be merely $18 \mathrm{Mm}$.

The construction of a shipping canal across the Vistula Spit has been the subject of discussions, and controversies, studies and scientific research for many years. The concept was presented for the first time in November 1945 in a memorial, which was an expert opinion by prof. S. Leszczycki, before work on delimiting the eastern border.

In the middle of the nineties, the Maritime Institute in Gdańsk developed a concept for linking directly the Vistula Lagoon with Gdańsk Bay. The suggested solutions base on the projects developed in 1996. New economic, social, political and legal regulations on environmental protection, including the European network of Natura 2000 are accounted for in the project, which foresees locating the canal near Skowronki in gmina Sztutowo. The canal is to become an element of the international marine route allowing for free passage of vessels between the Lagoonbased ports, the sea port of Elblag and the Baltic Sea. The projected canal, depending on the option chosen, will be 1100-1400 m long, $50 \mathrm{~m}$ wide and $5 \mathrm{~m}$ deep.The canal will include a lock fitted with storm gates. A road bridge (drawbridge, swing bridge or trestle bridge) is planned over the canal. The canal will provide a passage for yachts and ships. The biggest cargo ships to pass the canal will not exceed $90 \mathrm{~m}$ in length, 12 breadth, and a draught of $3.2 \mathrm{~m}$, and in the case of passenger ships, vessels of up to $60 \mathrm{~m}$ in length, $12 \mathrm{~m}$ in breadth and a draught of $2.5 \mathrm{~m}$. (Kowalczyk, Łuczak 2007). Its construction will reduce the distance to TriCity ports. The main outskirts of Elblag, Tolkmicko and Frombork ports, apart from Kaliningrad port will be Gdańsk and Gdynia. Thus, the TriCity, would reinforce its influence on the Spit and Lagoon located gminas, especially in the summer season.

From the economic perspective the benefits of building the canal could also be felt by the Kaliningrad Oblast'. Every investment in providing better access to this closed water basin is beneficial for all. The restrictive aspect of the shipping ban on the Russian side of the Lagoon will become insignificant. Shipping from Elblag to Baltiysk and Elblag to Kaliningrad will in this situation be possible. The route will be slightly longer but open to bigger and faster vessels. With the opening of the Strait of Baltiysk these connections for international shipping could also be provided by other than Polish vessels. The construction of the canal means more than just a new transport route as it will also become a stimulating factor for the econo- 
my of Lagoon coastal gminas. It will ensure spatial integration of Gdańsk Bay and the Vistula Lagoon. New options for developing tourism and marine recreation will be provided. This regards both passenger tourism on water from Gdańsk and Gdynia and individual yachting.

The canal project, though listed among strategic investments under the program "Infrastructure and Environment" adopted by the Council of Ministers of the Republic of Poland was, due to financial reasons in 2009 postponed to the future.

Thanks to municipal and EU funds in the years 2004-2005, the port of Elblagg gained a modern cargo handling and warehousing terminal covering an area of 5 ha and handling capacity of 600 thousand tons per year, as well as a passenger ferry terminal compliant with all Schengen requirements. There are also plans for modernising the yacht marina.

\section{CONCLUSIONS}

For centuries shipping on the Vistula Lagoon faced various obstacles, mainly of natural environmental character. In XX century political barriers became the dominant aspects. Although work on the canal concept was suspended, the new agreement on shipping signed in 2009 gave rise to hope for reinstating a fleet of passenger and merchant ships. This in turn may have a positive impact on reviving tourism and economic development in the Polish and Russian part of the Vistula Lagoon. Stimulation of shipping and small Lagoon ports may provide an incentive for the development of marine and coastal tourism as well as the development of new, partner crossborder relations between Poland and the Kaliningrad Oblast'.

\section{REFERENCES}

Bugajski, D.R. (2006), Polska i międzynarodowa żegluga w Cieśninie Piławskiej, Polski Przeglad Dyplomatyczny, 4 (32).

Frankowski, P. (2010), Później, czyli nigdy, Namiary na Morze i Handel, 1.

Kowalczyk, U., Łuczak, B. (2007), Przekop w pełni realny, Namiary na Morze $i$ Handel, 1.

Luks, K. (2006 a), Warunki uprawiania żeglugi na Zalewie Wiślanym, Przeglad Morski, February.

Luks, K. (2006 b), Otworzył zalew na Europę, Namiary na Morze i Handel, 23.

Modzelewski, W. (2006), Żegluga po Zalewie Wiślanym jako kwestia sporna w stosunkach polsko-rosyjskich, in: Hołub A. (ed.), XXI wiek—era kryzysu czy odnowy kulturalnej i politycznej, Olsztyn.

Palmowski, T. (1993), Polskie porty i przystanie Zalewu Wiślanego, Nautologia, 3. 
Palmowski, T. (1996), Aktywizacja Zalewu Wiślanego w perspektywie wspótpracy $z$ regionem królewieckim, in: Lijewski T. and Kitowski J. (eds.), Prace Komisji Geografii Komunikacji PTG, Volume I, Warszawa-Rzeszów.

Palmowski, T. (2001), Port elblaski—dawniej i wspótcześnie, in: Lijewski T. and Kitowski J. (eds.), Prace Komisji Geografii Komunikacji PTG, Volume VII, Komisja Geografii Komunikacji PTG w Warszawie, Wydział Ekonomiczny Filii UMCS w Rzeszowie, Warszawa-Rzeszów.

Socha, R. (2006), Marzenia o mierzei, Polityka, 38 (2572).

Strzelczyk, J. (2002), Ucieczka ze wschodu. Rosja w polskiej polityce 1989-2002, Oficyna Wydawnicza Rytm, Warszawa.

Szermer, B. (1987), Perspektywy portowe Elblaga, Technika i Gospodarka Morska, 12. 
http://rcin.org.pl 